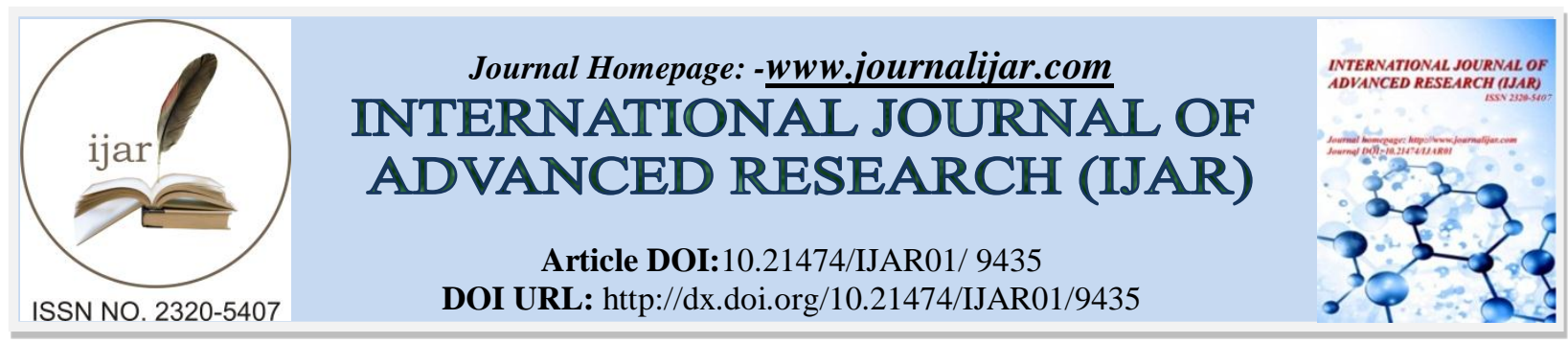

RESEARCH ARTICLE

\title{
FOREIGN AID, ASSISTANCE AND GRANTS AS TOOLS FOR THE UNDERDEVELOPMENT OF AFRICA.
}

Aboh James Ajang and Egbe Boypa Oyama ${ }^{2}$.

Department of History and International StudiesUniversity of Calabar, Nigeria.

\section{Manuscript Info}

Manuscript History

Received: 24 May 2019

Final Accepted: 26 June 2019

Published: July 2019

Key words:-

Foreign aid, donor nations, developing economies, third world countries, underdevelopment, collective bargaining.

\begin{abstract}
The widespread belief across the globe and across religions that the rich should help the poor through Aids makes aid beneficiaries to undermine its consequences. Rather than being the cure for the ailment of poverty, Foreign aid is indeed the disease that plagues third world countries and developing nations of the world and which plunges them into more poverty. This is made possible through the conditions attached to the Aids and Grants given to these countries. The benefiting nations feel they are benefitting from a great favour, but the donor nations know what they want. These grants, more often than not, weaken the bargaining power of receiving nations; hence the principle of collective bargaining is, in most cases, violated. Foreign aids are mostly "Greek gifts", which benefiting nations take for granted. This paper x-rays the benefits or otherwise of the different aids and grants given to third world countries, especially African countries. The paper concludes that rather than developing the economies of the third world, aid has been and will continue to be a clog in the wheel of progress of developing economies and indeed a monumental humanitarian disaster for most part of the developing world.
\end{abstract}

Copy Right, IJAR, 2019,. All rights reserved.

\section{Introduction:-}

Virtually all religions across the globe encourage assistance to those in need in the form of aids, grants, loans, gift, among other forms but these religions add that such assistance should be unconditionally free of any motive. It is also true that all people are not the same neither are nations, no matter how hard people or nations struggle, one must be better than the other materially or otherwise hence the need to assist those challenged materially and or physically. Secondly, distribution of natural resources, climatic conditions, civilizations, soil texture and cultures are skewed across the globe. The above justified the popular trade by batter and buttresses need for assistance. Thirdly, some people and nations render assistance for the purpose of pride. This group of people or nations offer assistance or gifts when they do not have. They go loaning to assist either for pride or to win the recipient's support for one greater advantage or the other. The principal culprits of this phenomenon are the Breton wood institutions, which forms the basis of investigation of this paper.

Niall Ferguson in a forward to Dambisa Moyo's book Dead Aid notes that despite the widespread Western belief that 'the rich should help the poor, and the form of this help should be through aid', the reality is that aid has helped to make the poor poorer, and growth slower. Infact, Moyo herself maintains that aid has been and continues to be an

Corresponding Author:-Aboh James Ajang.

Address:-Department of History and International StudiesUniversity of Calabar, Nigeria. 
unmitigated political, economic, and humanitarian disaster for most part of the developing world. She likens aid to what Karl Kraus said of Freudianism, that aid is the disease of which it pretends to be the cure.

\section{On the Eve of Giving and Receiving}

Giving and receiving are juxtaposed, one connotes 'superiority' while the other speaks to 'inferiority', but one event leads to all and that is the people's psychology. Psychology is the scientific study of behaviour, mental process and experiment of living organisms (Eriega2001). The Psychology of man is majorly influenced by society and environment. Isangedighi (2010) argues that the home serves the important function of providing the need of the child. Irrespective of the culture, some children find themselves in enviably endowed home that is well equipped to meet their needs. Some find themselves in improvised home environments where their needs are hardly adequately satisfied. So each grow toward adulthood with his own peculiar nature and unique environmental influence. Isangedighi further holds that 'children have needs which emerge from situational variables; they also have needs that are universal. Universal needs are those that are common to all children irrespective of rearing practice in their own culture. This clearly illustrates how people can be psychologically influenced by society and environment.

Against this backdrop, therefore, the over a century and a half of European domination, exploration, intimidation, rape and plundering of Africa greatly eroded and diluted these experiences. The society grew on these templates with far reaching economic, social, political and cultural consequences. Frantz Fanon saw how the psychology of the colonised was messed up by the growth of the society on these templates. In Black Skin, White Masks, he observes how the black man's inner world of thought images, values and perception is taken over by this western mode of thought and "civilization." The black man, as it were, is dehumanized and cannot really discover for himself his own future, unless he decolonises his mind. In The African Mind and Globalisation: Rethinking the Causes of Africa's Underdevelopment, Bassey Oben (2014) seems to agree with Fanon that the "African mindset" or psychological colonization is what inhibits the African from advancing technologically. The African grows up traditionally to see science as something beyond his reach and being content to go only as far as administering the instrument of oppression that white colonization has put up to keep him in the position of servitude.

In analysing the history of Africa from pre-colonial to post-colonial times, Walter Rodney frowns at the incorporation of Africa into the European idea of development through imperialism as essentially a process of under developing Africa. This process has not really come to an end. The technological superiority of the West over Africans and the unequal trade and exchange that globalization imposes on Africans, combined with the psychological operation, these objectives of underdevelopment creates a much more burdensome situation for Africa to develop than can easily be discerned from casual observation.

Thus, both at the subjective level of conceptualising reality and the objective level of interacting with other human societies through trade, politics and economic well being, the African has to deal with this historical past and structural intermeshing with western civilisations. It comes in the form of language and thought. It also comes in the forms of institution and what we regard as modern. And it comes, finally, in terms of what government exist to do and what families, individuals and communities should do for themselves.

Oral interview conducted in Nigeria early in 2016 by these writers reveal that majority of Nigerians believe that what the country is going through today is the manifestation of colonialism. Of course some argue in favour of colonisation and wish that the Europeans be called back, stressing that there was in sense of law and order in the colonial times than it is now. This investigation further reveals that holders of this view are very poorly enlightened, poorly exposed and are mainly artisans and frustrated politicians. In fact, the people under this category are like the biblical Israelites who, because of cucumber, wanted to remain in Egypt. Those in the former school of thought are scholars, technocrats, bureaucrats and diplomats. For these ones, colonialism has greatly punished Africa and Africans.

\section{Africa's Poverty Level}

Merian Webster's Dictionary defines poverty as 'the quality or state of being poor or indigent; want or scarcity of means of subsistence; indigence; need'. 'It is the inability to attain minimal standard of living' (World Bank, 1990:26). Poverty is a form of economic deprivation. While hunger is the target of poverty, disease is closely associated with it. In fact, Soroka and Bryjak (1992) opine that 'poverty can be measured as incomes that fall below the amount of money needed for a minimally adequate supply of material resources such as food, clothing, and shelter'. Offiong D. (2001) Observes that there are two types of poverty, absolute and relative, but what is important 
and is the concern of this paper is that poverty implies a level of income that imposes real physical suffering on people in hunger, disease and so on, culminating in the untimely death of those affected when they cannot assess the basic necessities of life. Offiong further argues that poverty is destructive "in the sense that it can obsess one's thought and divert him from the enjoyment of his life',

With an average per capita income of roughly US\$1 a day, Sub - Saharan Africa remains the poverty headquarters of the world. Moyo emphasises that Africa's real per capita income today is lower than in the 1970s, leaving many African countries at least as poor as they were forty years ago. With over half the population living on less than one dollar a day, sub - Saharan Africa has the greatest proportion of poor people in the world. Between 1980 and 2002 according Moyo, the number of people in Africa living in abject poverty doubled, leaving the average African poorer today than just two decades ago.

Poverty as said earlier is synonymous with hunger, diseases and death. Accordingly, life expectancy will either stagnate or decline. Africa is the only continent in the world that life expectancy is less than sixty years, In fact today, it should be hovering around fifty and forty years. The decrease in life expectancy is mainly attributed to HIV and AIDS pandemic.

Dambisa Moyo concludes that foreign aid has not lived up to expectation. It remains at the heart of the development agenda, despite the fact that there are very compelling reasons to show that it perpetuates the cycle of poverty and derails sustainable economic growth. Paul Kagame rightly also laments that "while more than US\$300 billion has apparently been disbursed to our continent since 1970, there is little to show for it in terms of economic growth and human development'". Aid is therefore not working, why?

\section{The Role of Breton Wood Institutions in the Underdevelopment of Africa.}

The International Monetary Fund (IMF), World Bank and other lending (donor) agencies are the most powerful international financial institutions in the world today. They are the major sources of lending to African countries and use the loans they provide as a proviso to prescribe policies and dictate changes in the economies of these countries. Through loans and their conditionalities, these institutions and their backers compromise the sovereignty of beneficiary countries. The World Bank, for example, is the largest public development institution in the world, lending over \$24 billion in 2007 of which over \$5 billion or 22 percent went to Africa. (World Bank Development Indicators 1990).

The World Bank and IMF are controlled by the world's richest countries. The U.S. is the main shareholder in both institutions. The World Bank, headquartered in Washington DC, follows a "one dollar, one vote" system whereby members with the greatest financial contributions have the greatest say in decision making. The U.S. holds roughly $17 \%$ of the vote in the World Bank and the 48 sub-Saharan African countries together have less than $9 \%$ of the votes. The Group of 7 rich countries (G-7) controls $45 \%$ of World Bank votes. This system ensures that the World Bank and IMF act in the interest of the rich countries, promoting a model of economic growth (called neo-liberal) that benefits the rich countries and the international private sector (WBDI 1990).

The World Bank and IMF attach strict conditions to their loans, which give them great control over borrower governments. On the average, low-income countries are subject to as many as 67 conditions per World Bank loan. As a consequence, most African countries, under pain, have had no choice but to accept these conditions.

\section{IMF and World Bank Loan Policy Framework}

The World Bank and IMF have forced African countries to adopt "Structural Adjustment Programs" (SAP) and other measures which cut back government spending on basic services. They have required African governments to reduce trade barriers and liberalise their markets, maintaining their economies as sources of cheap raw materials and cheap labour for multinational corporations.

As a result of World Bank and IMF policies toward Africa in particular, average incomes have declined, and the continent's poverty level has increased. Africa's debt crisis has worsened over the past two decades. World Bank and IMF interventions have left African countries more dependent than ever on new loans. These institutions have also undermined Africa's health condition through the policies they impose. The general conditionalities of the IMF to the needy countries as captured by Aja Akpuru- Aja (2001) include:

1. The capacity to repay in hard currency 
2. The evidence of economic reforms or restructuring to eliminate or control the causes of balance of payment deficit.

3. The preparedness and/or openness to involve the IMF technical crew in proposing, designing and executing of capital projects.

4. The evidence of governmental stability, and

5. A guarantee that the recipient country is not reactionary or communist inclined.

The specific conditionalities of the IMF to the needy countries include:

1. Devaluation of national currency and that is a reduction in the exchange value of a country's currency in relation with international monetary and exchange regime.

2. Wage free/retrenchment of workers is a measure to reduce supposedly government (wasteful) expenditure.

3. Reduction in government social and welfare expenditure such as removal of subsidies, and deregulation of any sectoral control by the government (e.g. the oil industry in Nigeria).

4. Trade liberalization which allows greater free flow of imports - exports, capital, labour, foreign direct investment and market offerings.

5. Privatization and commercialization of economic realms or public enterprises. For clarity, privatisation has to do with the sale of public enterprises to the private sector for more fruitful and productive management. Commercialization represents the introduction of profit making motive in the management of public enterprising with greater assurance of efficiency of services. Downsizing the state's control of the economy is designed to align with the capitalist value system. Invariably, it is an exercise which encourages that a state intervenes least in the economic activity with a view to allowing the private sector to engineer economic growth and development.

6. Review of interest rate(s) periodically.

Rourke J T (2007) opines that critics also accuse the IMF of imposing unfair and harsh conditions on countries that borrow from it. Most IMF loans are subject to conditionality. This refers to requirements that the borrowing country take steps to remedy the situation that according to him, IMF have caused the recipient's financial problems. He maintain that this conditions generally press the less developed countries to move toward capitalism and free international economic exchange by such as privatizing state-run enterprises, reducing barriers to trade and investment, and devaluing currencies to increase exports and decrease imports.

For these reasons, the policies of the World Bank and IMF have increasingly come under fire for the negative impact they have had on African countries. But these institutions, the U.S., and other wealthy countries that control them, have refused to address these concerns. Instead, they have continued to use Africa's debt crisis as a pretext to maintain control over the economies of African countries. Jackson R \& Sorensen G (2007) argued that rather than sustaining the 1945 post war liberal world economy, the US adopted protectionist measures to support its own economy. Even as Africa faces the worst health crisis in human history, these institutions insist that debt repayments take priority over spending on the fight against poverty and such pandemic as HIV/AIDS. On the average, African countries have continued to spend a sizeable percentage of their incomes on debt servicing than on health care of their populations.

Following the public outcry of humanitarian, civil society organisations and other well wishers, Breton Wood institutions try to address the situation with the foregoing;

\section{Addressing External Debt Crises}

To address the external debt crises of poor countries, the IMF and World Bank introduced the Heavily Indebted Poor Countries (HIPC) initiative in September 1996. Designed by creditors, this initiative was intended to extract the maximum in debt repayments from poor countries. It has failed even to meet its stated objective of reducing Africa's debt burden to a "sustainable" level, and the strict HIPC eligibility requirements prevent many countries from receiving much-needed assistance.

In July 2005, the Group (G-8) proposed a debt cancellation deal for 18 countries, 14 of which are in Africa. That September, the World Bank and IMF approved this deal through the Multilateral Debt Relief Initiative (MDRI). The MDRI grants debt cancellation to countries that meet certain eligibility requirements, including adherence to economic policies and programs that the World Bank and IMF deem satisfactory.(WBDI 2009). The IMF is not a 
charitable organisation but a business portfolio, the meaning therefore is that needy countries most meet their conditions, which include the readiness to take policy steps in support of adjusting or restricting their economies.

\section{Managing Future Economic Challenges}

In recent years, there have been encouraging economic trends in many African countries, an increase in real growth rates, a decline in inflation, and a narrowing of financial imbalances. After declining in the 1980s and the early 1990s, average real per capita income in sub-Saharan African grew at an annual rate of 1.5 percent during the second half of the 1990s. In the later period, growth performance improved in 37 of the 47 countries in sub-Saharan Africa. The region's fiscal and external current account deficits have shown declining trends. Moreover, the continent's two largest economies, South Africa and Nigeria, are today more than ever before, well positioned for stronger economic performance. There is, therefore, encouraging evidence that economic reform efforts in Africa are beginning to show positive results.

While the recent improvements in economic performance are heartening, there is no doubt that much more remains to be done. Poverty remains widespread. Private investment is subdued. The economies of sub-Saharan Africa have remained largely undiversified, hence, highly vulnerable to changes in external conditions. In several cases, an already fragile economic situation has been weakened severely by ongoing conflicts.

\section{Financing in Support of Adjustment Programs}

To make the fight against poverty effective, it will be essential to design the policy framework with a view to achieving clear goals for broad social progress as rapidly as possible. With this in mind, the Interim and Development Committees of the Fund endorsed the adoption of an enhanced framework for poverty reduction by low income countries. They also endorsed the replacement of the Enhanced Structural Adjustment Facility (ESAF) by the new Poverty Reduction and Growth Facility (PRGF). All PRGF supported programs would be drawn from the country-led PRSPs; the targets and policies embodied in PRGF programs would emerge directly from the country's poverty reduction strategy. Sustainable poverty reduction would be at the centre of all new growthoriented adjustment programs.

\section{Assistance to Post-Conflict Countries}

In post-conflict countries, the Fund's role should be seen as an integral part of a broader coordinated strategy by the international community to ensure the maintenance of peace and an orderly transition from conflict to conditions conducive to stabilization and sustained growth. The IMF has worked closely with the UN in post-conflict cases (such as Angola, Rwanda, and Sierra Leone), including as a member of the Interagency Working Group on PostConflict Situations. After the end of a conflict, coordination of technical and financial assistance is particularly important because of the disruption of normal relations that often occurs during the period of the conflict, as well as the need to rapidly rebuild institutional and administrative capacity, and, in some cases, ensure that a peace settlement is consistent with a sustainable macroeconomic framework (CBN Statistical Bullatin 2008).

\section{Setting up Transitional Arrangements}

To bring as many eligible countries as possible to their decision point under the HIPC Initiative, a period of transition is envisaged during which policies can be formulated without disruption to ongoing concessional support from the Fund and the Bank to low-income countries. This document would present (1) the broad elements of the poverty reduction strategy, and indicate a time frame and consultative process for the elaboration of a full-fledged Poverty Reduction Strategy Paper (PRSP); (2) a jointly agreed three-year macroeconomic framework; and (3) a policy matrix focused on poverty reduction. Policy commitments and targets for the outer years would be revised as the interim document is developed into a full-fledged PRSP. Although the length of the transition period would depend on the individual country's circumstances, it is generally expected that the first PRSP could be produced within two years or less, so that only one interim PRSP would be necessary (CBN,SB. 2008).

\section{Technical Assistance and Capacity Building}

The envisaged far-reaching reform efforts will require a strengthening of domestic institutional and administrative capacities. In this context, we all should recall that the Partnership for Capacity Building in Africa has stressed the need for a targeted and strategic approach to capacity building and institutional reform. This means that African governments, as well as their multilateral and bilateral partners, will need to work closely together to help achieve this goal. 
The IMF Institute channels a significant share of its training resources into cooperation with regional training institutes in Africa it also organizes high-level seminars that bring together senior officials of African governments to exchange views on policy issues of special relevance to their region, drawing on lessons from the experiences of others.

Moreover, the Fund is providing substantial technical assistance to member countries in a broad range of macroeconomic policies, and it is expected to intensify these efforts in light of the assessments and action programs for enhancing capacity in individual countries. Most important, capacity building will continue to be stressed in countries implementing adjustment and reform programs supported by the Fund's PRGF. While devoting efforts to build home-grown capacity to formulate and implement appropriate policies, governments will also need to focus on the urgent task of articulating and pursuing sound policies, availing themselves as necessary of technical assistance from their development partners. It will also be important to ensure that the envisaged reforms, particularly in the public sector, are formulated in a way that is compatible with the thrust of adjustment policies and fiscal sustainability.

\section{Challenges and Failures}

Despite the billions of dollars spent each year by the IMF and World Bank in sub-Saharan Africa, the disparity between rich and poor continues to grow at an alarming rate. It has become abundantly clear to not only those in need, but also to scholars, diplomats and economists, that increased funding does not alone decrease poverty. There needs to be solid demand-based loan allocation backed by ethical policies to make aid effective in improving the human rights conditions of the most deeply impoverished and marginalized in sub-Saharan Africa.

The IMF and World Bank historically and to date receive their funding mainly from members in developed countries. It has been common practice since their inceptions that the IMF and World Bank act much like any financial institution by placing stipulations on borrowed money. The IMF labels these stipulations "conditionalities." The IMF uses conditionality as a deterrent for noncompliance and default on lending. Through conditionality, the IMF is able to put restraints and restrictions on certain actions, as well as prescribe requirements, such as privatization on borrowers. Non-compliance with IMF conditionality can place borrowers' international credibility at risk, jeopardizing the potential for future lending and risking premium interest rate hikes. For the most impoverished countries in SSA, conditionality is yet another barrier to improving their economy and subsequently, their human rights records.

Current aid allocation in SSA relies on measurements of economic policy. Measuring a country's need based solely on its macroeconomic (fiscal, monetary, exchange rate) and structural (trade, tax) policies are form of static poverty analysis. This system of measurement relies on the expenditure of a household at one given time; lacking the necessity to evaluate the evolution and transitory nature of poverty within a society. Conditionality and allocation work together to become a vicious cycle that impoverished states can easily get trapped in. In this context, human rights violations have a greater opportunity to flourish.

Aid planners set objectives and goals for allocation, based on what they believe are necessary changes for the borrower. This highly subjective process is frequently affected by outside sources, such as donor countries who want to see "big change" or individuals within the IMF or WB that want to implement new strategies. Political agendas take priority and little if any effort is given to assessing the historical, cultural and traditional factors that may impede aid effectiveness. Terms such as "lender" and "borrower" reduce foreign aid to quantitative figures; when in reality the necessity lies in seeing the potential human impact, both positive and negative, that IMF and World Bank aid can bring.

\section{Conclusion}

Sub-Saharan Africa is a place of unequivocal beauty, diversity and history; it is also the most impoverished and neglected area on the planet. With an objective look at what has gone wrong in the past five decades of International Monetary Fund and World Bank lending, along with strategic assessment and planning, Sub-Saharan Africa does not have to remain the home to unimpeded rampant poverty. Development aid is a post-World War II phenomenon. The "Breton Woods" nations understood the need for multinational and multilateral institutions whose sole focus would be economic development. In 1944, with these intentions in mind, the International Monetary Fund (IMF) and its sister organization, the World Bank (WB), began their long legacies of universal lending. The IMF was, and still is, intended to perform two main tasks: to monitor member states' economies and to act as an international 
lender. Still performing these tasks, the IMF has allowed the latter to become its main purpose. With a growing alliance of developed nations, the IMF and WB have the ability to give sub-Saharan Africans the tools they need to live healthy, productive, and happy lives that are free from the current hell inherent in living in the world's most impoverished conditions.

On the part of African nations, since IMF and World Bank will not relax its conditions for reasons best known to them, they require elected people oriented and God fearing leaders who have empathy for their citizens to manage the economy of their states. They should as a matter of urgency, have respect for the rule of law, strengthen government institutions and ensure that things go the way they should go. It is only in doing this that their countries will profit maximally from the regular billion dollars of aid funds coming from Breton Wood institutions. Alternatively, African governments should discourage the acceptance of some of these Aids that come with severe consequences to their local economies. What they lack, they should invent alternatives, after all, necessity is the mother invention.

\section{Works Cited:-}

1. Aja A. A. (2001). Selected Themes in International Economic Relations Understanding Trends of Globalization and Regionalization. Rhyee Kerex Publishers and Keny and Brothers Enterprises, Enugu.

2. Bryjak GJ \&Soroka MP (1992). Cultural Diviersity in a Changing World. Boston, Sllyn and Bacon.

3. Central Bank of Nigeria (CBN) Statistical Bulletin, 1985, 1990, 1998 and 2006

4. Eriega G N. (2001). Understanding Development Psychology. Port Harcourt: Abe Publishers (Nigeria) Limited.

5. Fanon F. (1967). Black Skin White Masks. London; Penguin.

6. Isangedighi J A. (2010). Education a Modular Review, Vol. 1. Calabar: Eti-Nwa Associates.

7. Jackson R \& Sonrensen G. (2001). Introduction to International Relations: Theories and Approaches. Oxford London.

8. Moyo D. (1994). Dead Aid; Straus and Giroux, New York.

9. Oben, Bassey (2014). "The African Mind and Globalisation: Rethinking the Causes of Africa's Underdevelopment" in LWATI: A Journal of Contemporary Research, Vol.11/3, 20 - 27.

10. Offiong D. (2001). Globalisation: Post-Neodenpendency and Poverty in Africa. Fourth Dimension Publisher, Enugu.

11. Rodney W. (1973). How Europe Underdeveloped Africa. Dar es Salaam: University of Dar es Salaam Press.

12. Rourke J. (2007). International Politics on the World Stage. Mc graw Hill. Boston.

13. World Development Indicators, 1990, 2000, 2015. 